\section{Meta-analysis of the antecedent and consequent constructs of materialism}

\author{
Fernando de Oliveira Santini 12 \\ ${ }^{1}$ Universidade do Vale do Rio dos Sinos (Unisinos), Faculty of Business \\ Administration, Accounting and Economics, Business School, São Leopoldo/RS, \\ Brazil; ${ }^{2}$ Escola Superior de Propaganda e Marketing (ESPM), Business School, \\ Porto Alegre/RS, Brazil

\section{Wagner Júnior Ladeira} \\ Universidade do Vale do Rio dos Sinos (Unisinos), Faculty of Business \\ Administration, Accounting and Economics, Postgraduate Program in \\ Management, São Leopoldo/RS, Brazil

\section{Cláudio Hoffmann Sampaio} \\ Clécio Falcáo Araújo \\ Pontifícia Universidade Católica do Rio Grande do Sul (PUC-RS), \\ Business School, Postgraduate Program in Management, Porto Alegre/RS, Brazil
}

\begin{abstract}
Purpose - Materialism has been gaining ground in the academic field, especially from the 1980s on, given the relevance of understanding sentiments connected to possessing and acquiring goods. Thus, this meta-analysis was carried out to assess the antecedents and consequents of materialism.
\end{abstract}

Design/methodology/approach - Based on a systematic review, we gathered a total 77 articles that examined those aspects, generating 99 effects-sizes and a cumulative sample of 40,288 studied individuals.

Findings - The antecedents of materialism that showed a significant relationship with this construct were: perceived hedonic value, interpersonal influence, life satisfaction, and income. As for the consequents, we observed significance for purchase intention, impulsive buying, compulsive buying, conspicuous consumption, status consumption, and consumer involvement. Regarding the moderating effect, we observed that small samples produce greater effects. Furthermore, for the relationship between materialism and purchase intention, there are stronger effects for surveys conducted in Western countries.

Originality/value - Based on the methodology applied in this study, we expected a solid and generalizable contribution regarding construct materialism.

Keywords - Materialism; antecedents; consequents; meta-analysis.
Received on

$01 / 15 / 2016$

Approved on

03/16/2017

\section{Responsible editor:}

Prof. Dr. Guilherme Shiraishi

Evaluation process:

Double Blind Review

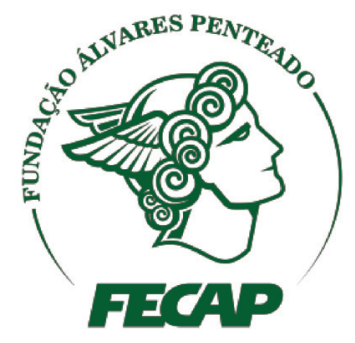

Review of Business Management

DOI: $10.7819 /$ rbgn.v0i0.2931 


\section{Introduction}

The act of consuming a product or a service is not simple, since it is fraught with cultural and symbolic characteristics (Belk, 1982). This act becomes more complex with each new generation of consumers, raising issues referring to the (re)affirmation of identity, the definition of social status, to belonging to a group and to the definition of hierarchy, status or power (Flynn et al., 2013; Tsang et al., 2014). In this complex scenario, materialism has been increasingly used to explain this complexity (Hudders \& Pandelaere, 2012; Chan et al., 2015).

The materialism construct has been gaining increasing academic notoriety, especially following a study conducted by Belk (1985) in the Journal of Consumer Research. The author defines it as the importance given to owning goods, highlighting how people who internalize this feeling are oriented towards material goods and money, which are essential elements to their happiness (Ward \& Wackman, 1972; Richins $\&$ Chaplin, 2015). Thus, materialist individuals consider possessing goods decisive to their lives, and this may even become a guiding element in the satisfaction or dissatisfaction of their wellbeing (Watson, 2003).

In this sense, materialism has become a common construct in marketing studies (Benmoyal-Buzaglo \& Moschis, 2010; Donnelly et al., 2013; Segev et al., 2015)

It is made up of observable variables that measure the importance attributed to possessing and acquiring material goods to achieve life goals or a desired status (Goldberg et al., 2003). Thus, understanding the "origins" (antecedents) and the "purposes" (consequents) of materialism in the act of consuming is crucial to better measuring this construct.

Based on this fact, several studies have been carried out; they have become more frequent from the 1990s on, seeking to understand what motivates and what results from consumers' materialistic behavior. However, results do not always converge regarding this understanding. For example: the interpersonal influence antecedent reveals a negative (Wan et al., 2009), positive (Fitzmaurice \& Comegys, 2006) or neutral relationship with materialism (Benmoyal-Buzaglo $\&$ Moschis, 2010). There are also divergent results for the consequents of materialism, as can be observed for the compulsive shopping construct; positive (Weaver, Moschis \& Davis, 2011) and negative relationships (Richins \& Dawson, 1992) can be found.

There are doubts, therefore, regarding the real effects of materialism. Based on this fact, this study carried out a meta-analysis of empirical studies on the subject, in order to identify possible antecedent, consequent and moderating constructs that may affect these relationships. The statistical method we used allows for calculating the magnitude of each relationship considering sampling and measurement errors, providing a path for empirical generalization of this behavior (Farley et al., 1995), taking antecedents and consequents into account. When pursuing this goal, we found 77 articles that examined those aspects, generating 99 effects-sizes that were subject to this meta-analysis.

We expect this study to contribute to this field of knowledge, mainly with regard to materialism, due to the following aspects: a) unlike traditional reviews, meta-analytic research reaches conclusive definitions on the investigated subject - in this case, materialism - from studies conducted in various different contexts (Green, 2005); b) meta-analysis goes beyond possible biases associated with studies that are conducted and published with a number of limitations (e.g., sample size and sample type, methodological robustness), and allows for generating accurate estimates of size of effect in each analyzed relationship (Lipsey \& Wilson, 2001); c) metaanalytic research allows for analyzing in a conjunct and generalizable manner results generated by studies using different methodologies, samples, data collection and analyses (Dickersin, 2002); d) meta-analysis allows for accurate conclusions, 
unlike any other primary study (Hunter \& Schmidt, 2004); e) conclusions reached by this method set standards for what is considered the state of the science, what we know and do not know and which theory is valid or not (Schmidt, 1996).

Structurally, this study begins discussing materialism and its possible relationships. Next, the establishment of hypotheses (antecedents and consequents) describes the data collection process for meta-analysis, followed by interpretation and analysis of results. Finally, we present our final considerations.

\section{Materialism}

Materialism, from an anthropological point of view, is the relentless pursuit of status and power (Belk, 1985). Consumers who present these characteristics do not necessarily desire status, but to impose an identity to society. That is, an individual must reaffirm his own identity facing others (Micken \& Roberts, 1999; Chang \& Arkin, 2002)

Regarding the establishment of scales to measure materialism in marketing, Belk (1982) presented a multidimensional measure comprising three feelings: a) envy, in which a negative predisposition toward another individual is evoked because of the success of the latter; b) possession, in which the feeling of control is highlighted; and c) lack of generosity, in which an individual presents no predisposition to share something with others. In the 1990s, Richins and Dawson (1992) presented new operationalization for the materialism construct, comprising the feelings of centralization (acquisition of goods as the center of life), happiness (acquisition of goods in pursuit of happiness) and also success (defined by ownership). According to the authors, materialists' main focus is the sense of ownership and acquisition.

Over ten years later, Richins (2004) improved the scale previously proposed by Richins and Dawson (1992), and introduced a new measurement scope. This improvement made important contributions: a) more satisfactory reliability indexes than those previously found; and b) reduction in the number of measurement items. Given the proliferation and consolidation of the scales, research on materialism evolved based on applied research in different countries and contexts. From then on, antecedents and consequents were established; they will be presented below in the form of hypotheses.

\section{I The antecedents of materialism}

Considering the analysis of the main scales that measure materialism (Belk, 1985; Goldberg et al., 2003; Richins \& Dawson, 1992), a search was carried out in databases and articles showing the main antecedents of materialistic behavior, provided these studies presented at least three observations per construct, as required by Hedges and Olkin (1985), to conduct meta-analytical studies. Thus, six background constructs were identified (hedonic value perception, interpersonal influence, life satisfaction and consumer income, gender and age).

\section{I.I Hedonic value perception}

Hedonic value perception is connected to the emotional experiences of consumers (Holbrook \& Hirschman, 1982). We can state that hedonic value is characterized by the search for fulfilling wishes expressed in experiential consumption (Miller, 2000). As for materialism, researchers relate it to a sense of ownership often expressed by symbols and experiences (Micken \& Roberts, 1999). Thus, it is feasible to propose that hedonic value perception positively relates to materialism. This assumption is supported by applied research in the context of branded clothing (Shukla, 2012) and luxury goods (Browne \& Kaldenberg, 1997; Sun et al., 2016). Thus, we suggest that:

H1: Hedonic value perception is positively related to materialism, i.e., the higher the hedonic value perception, the greater a consumer's materialism. 


\subsubsection{Interpersonal influence}

Interpersonal influence has been defined as the need for identification, improving an individual's own image according to the expectations of others (Kropp et al., 2005). This may occur in the acquisition and use of products and brands, in buying decisions and in the tendency to acquire products and services (Bearden et al., 1989). Thus, this behavior is directly associated with the acceptance of others (Kropp et al., 2005), reinforcing the recent findings by Gil et al. (2016), who discovered that the level of dependency to groups increases materialism. Based on this statement, it is feasible to assume a positive relationship between interpersonal influence and materialism, given that the latter, by means of ownership, seeks inclusion and social acceptance (Micken \& Roberts, 1999; Chang \& Arkin, 2002). This proposition is reinforced by research conducted in the Far East (Karabati \& Cemalcilar, 2010) and Europe (Shukla, 2012). Thus, we assume that:

H2: Interpersonal influence is positively related to materialism, i.e., the greater the need to identify with others, the greater a consumer's materialism.

\section{I.3 Life satisfaction}

Life satisfaction is understood as an overall assessment of well-being connected to the subjective judgment of each individual (Shin $\&$ Johnson, 1978). However, in general, it relates to aspects of health, interpersonal relationships, financial insouciance (Roberts \& Clement, 2007) and even religion (Rakrachakarn et al., 2015). On the other hand, materialism is characterized as a lifestyle based on the accumulation and purchase of goods that go beyond basic needs (Kasser, 2002). In this context, materialistic consumers cling to the importance of showing a positive image to others guided by status, wealth and financial success (Kasser, 2002). Studies such as those conducted by Belk (1985) and Richins and Dawson (1992) reported a negative relationship between materialism and life satisfaction. There are also relationships between materialism, high levels of depression (Kasser \& Ryan, 1993), low levels of gratitude (McCullough et al., 2002) and dissatisfaction with family life (Richins \& Dawson, 1992). Consolidating these findings, studies conducted recently give consistency to the assumption of a negative relationship between life satisfaction and materialism (Hudders \& Pandelaere, 2012; Tsang et al., 2014; Rakrachakarn et al., 2015; Gungordu et al., 2016). Thus, we suggest that:

H3: Life satisfaction is negatively related to materialism, i.e., the higher the levels of depression and dissatisfaction with experiences within the family, the greater a consumer's materialism.

\subsubsection{Consumer income}

Consumer income includes the financial investment capacity for the consumption of goods, thereby exerting great influence on buying behavior (Beatty \& Talpade, 1994) and guiding consumption experience and materialistic behavior (Joireman et al., 2010). In this sense, studies show that a high income tends to result in a greater propensity towards materialism, since it enables high availability and access to material possessions (Grotts \& Johnson, 2013; Flynn et al., 2013). Proof of this are applied studies in the luxury (Dubois \& Duquesne, 1993) and fashion sectors (Park et al., 2008), making a positive relationship between income and materialism evident. Therefore, we expect that:

H4: Consumer income is positively related to materialism, i.e., the higher the income for consumption, the lower the self-regulation and, consequently, the greater the propensity towards materialism.

\subsubsection{Consumer gender}

Differences in behavior between men and women have been widely investigated, since they 
may be considered market segmentation criteria. Accordingly, studies such as those conducted by Kempf et al. (2006), Kruger and Byker (2009) and Liao et al. (2009) show, respectively, that women are more detail-oriented in processing advertising information, more responsive to sales and more impulsive than men. These features support the hypothesis that women are more materialistic than men (Grotts \& Johnson, 2013; Flynn et al., 2013). Reinforcing this proposition, a recent research conducted by Lewallen et al. (2016) found that women are more susceptible to materialistic behavior than men when exposed to celebrity advertising. Thus, it is possible to assume that:

H5: Women are positively related to materialism, i.e., due to different personality traits that exist in the consumption levels of men and women, it is expected that women do more materialistic shopping than men.

\section{I.5 Consumer age}

According to the perspective of Belk (1985), consumers, when they reach an older age, are more mature and have greater contact with purchasing decisions processes; consequently, they present a lower predisposition towards materialism. On the other hand, the early stages of life are marked by a search for self-identity (Yang et al., 2008), which consequently leads to greater materialism. Thus, it is expected that materialism is more significant to younger than older consumers (Grotts \& Johnson, 2013; Flynn et al., 2013; Zaman et al., 2016). Thus, we suggest that:

H6: The younger an individual, the greater the materialism, i.e., the younger the consumer profile, the higher the inclination towards materialism.

\subsection{The consequents of materialism}

In addition to the identified antecedents, and based on the same procedures as mentioned above, this study found six types of consequents in literature: buying intention, impulsive buying, compulsive shopping, conspicuous consumption, status consumption and consumer involvement (see Figure 1).

\subsection{Buying intention}

It is assumed that materialism can relate positively with buying intention, since it is directly related to feelings of acquisition and possession (Belk, 1985). In this sense, studies conducted from the 1990 s on have already revealed significant relationships between the two behaviors (Browne \& Kaldenberg, 1997). More recently, Park et al. (2008), Chang and Zhang (2008), Wan et al. (2009) and Sun et al. (2016) ratified these effects. The first study found positive relationships between materialism and the buying intention of cars, clothes and homes; the second, of electronic games; the third, of CDs; and the fourth, of luxury consumption. Recently, research corroborating these findings has been conducted in different countries such as Brazil (Loureiro $\&$ Araujo, 2014), India, the United States (Shukla, 2012) and Israel (Efrat \& Shoham, 2013). Thus, we suggest that:

H7: Materialism is positively related to a consumer's buying intention, i.e., the higher the materialism, the greater the buying intention for products and services.

\subsubsection{Impulsive buying and compulsive shopping}

Impulsive buying is different from compulsive shopping because the latter can be considered a pathology, since the compulsive shopper finds it extremely difficult to control his or her actions based on environmental stimuli, a characteristic that is not necessarily found among impulsive buyers (O’Guinn \& Faber, 1989). On the other hand, the impulsive consumer is moved by a need to seek satisfaction (Park \& Lennon, 2006). The materialist, in turn, presents these two buying behaviors. Fitzmaurice and Comegys (2006) argued that materialistic consumers 
are more likely to remain longer in stores, and consequently spend more. That is, since they spend more time in a store, they are more likely to receive environmental stimuli, which is the guiding motive of purchases by both impulse and compulsion (O'Guinn \& Faber, 1989). Segev et al. (2015) corroborated this claim upon testing and confirming a positive relationship between materialism and time spent on a purchase. This interpretation is strengthened to the extent that there are numerous studies confirming the proposed results for a positive relationship between materialism and impulsive buying (Arocas et al., 2004; Sun \& Wu, 2011; Cakarnis \& D'Alessandro, 2015) and compulsive shopping (Reeves et al., 2012; Moschis et al., 2013; Lee et al., 2014). Thus, it is feasible to propose that:

H8: Materialism is positively related to impulsive buying, i.e., the higher the materialism, the greater the search for satisfaction in purchasing and the greater the impulsive behavior.

$\mathbf{H}_{\mathbf{9}}$ : Materialism is positively related to compulsive shopping, i.e., the higher the materialism, the greater the difficulty of an individual to control its actions based on environmental stimuli.

\subsubsection{Conspicuous and status consumption}

Conspicuous consumption has been defined as the action of purchasing a variety of products or services, usually expensive and unnecessary, in order to draw the attention of others (Shukla, 2008). Status consumption is characterized by the acquisition of something to provide identification of individual status, not necessarily for others (O'Cass \& McEwen, 2004). However, both constructs are positively correlated (Truong et al., 2008). Given these definitions, it is possible to assume a positive relationship between both behaviors and materialism. As previously mentioned, a materialistic individual is characterized by the accumulation of goods and services that go beyond basic needs, based on the importance he or she gives to presenting a sophisticated image (Kasser, 2002). The relationship of materialism with conspicuous and status behavior is proven by research results applied to the context of luxury goods and brands (Shukla, 2012; Chan et al, 2015), buying fancy cars (Sangkhawasi \& Johri, 2007) and, more recently, clothing (Loureiro \& Araújo, 2014). Thus, we suggest that:

H10: Materialism is positively related to conspicuous consumption, i.e., the higher the materialism, the greater the consumption of products to attract the attention of others, and therefore the higher the conspicuous behavior.

H11: Materialism is positively related to status consumption, i.e., the higher the materialism, the greater the acquisition of something to provide individual status identification.

\subsubsection{Consumer involvement}

Consumer involvement is related to the level of interest or importance given by an individual to a good, that is, the level of excitement that consumers feel for a product or a service (Richins \& Dawson, 1992). Thus, it is possible to assume that the higher the level of materialism, the greater the level of involvementt with a purchase. This assumption is supported by the relationship between materialism and purchase of goods (Belk, 1985), since an individual believes that ownership is a way of communicating to inform others what an individual he or she is (Manchiraju, 2015). This proposition is further consolidated by the findings of Browne and Kaldenberg (1997), Goldsmith et al. (2012), Handa and Khare (2013) and Manchiraju (2015), among others. Given this explanation, we suggest that:

H12: Materialism is positively related to consumer involvement, i.e., the higher the 
materialism, the higher the level of consumer purchasing involvement.

Once the study hypotheses have been discussed and presented, Figure 1 shows the theoretical model to be tested, containing constructs antecedents and consequents to material consumption. It also includes moderators to be tested and results of the analyses.
ANTECEDENTS

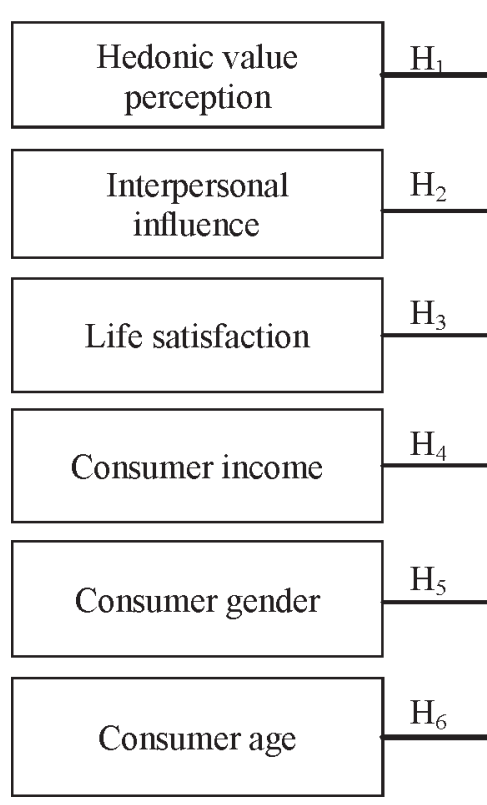

MODERATORS

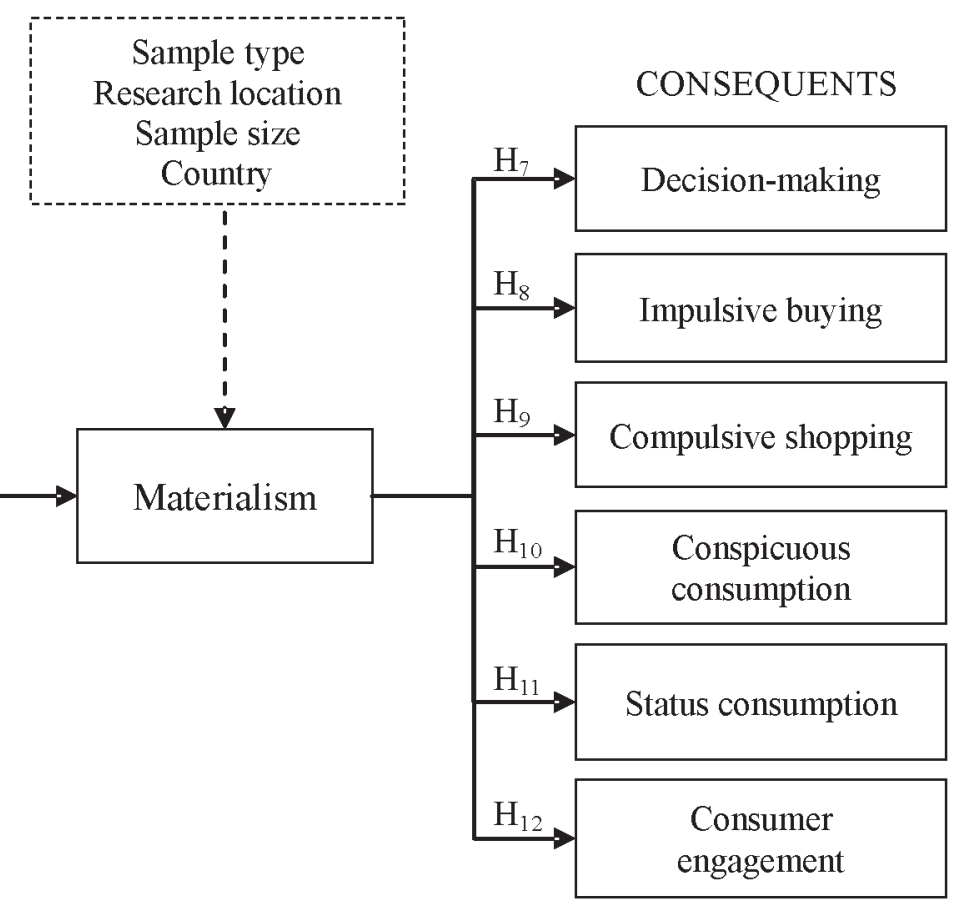

Figure 1. Hypothesized model of the antecedents and consequents of materialism

\section{Methodological procedures}

To perform the meta-analysis proposed in this article, the methodological procedures were defined based on studies by Moher et al. (2009). Information on library research, selection criteria, inclusion of studies and characteristics recorded on research published were prioritized using the terms "materialism" and "materialistic consumption" in marketing and psychology applied to marketing. In this context, the collection and analysis of the data development framework was segmented chronologically into four steps: record protocol and eligibility criteria, definition of information sources, collection process and researched variables, data manipulation methods and combination of results.
At first, we structured data collection. To do so, a record protocol, based on which eligibility criteria were established, was established to specify the study characteristics, respecting technical terms used in marketing and psychology publications. These characteristics involved, at first, scientific papers focusing on materialism found in articles in "marketing" and "psychology applied to marketing." Therefore, a decision was made to search for scientific articles in English, Portuguese and Spanish. In addition, the papers should be articles published in journals, dissertations or theses in marketing and psychology applied to marketing.

The definition of information sources directly involved thirteen databases: Jstor, CrossRef, Worldcat, Emerald, DOAJ, PsycINFO, Taylor 
\& Francis, Elsevier Science Direct, SCOPUS, Proquest, Scielo, Google Scholar and EBSCO. In addition, searches were conducted in theses and dissertations databases of the leading Master's and Doctoral programs in marketing and psychology.

For the process of collection, the search of variables containing the terms "materialism", "materialism", "consumo materialista", "el consumo materialista" and "materialistic consumption" in the fields "document title" and "abstracts" was performed using the search tool of the thirteen databases and Master's and Doctoral programs, according to the specifications mentioned above. In total, 266 articles on materialism applied to marketing were found. Later, a book report was made for each study, enabling viewing the method and the scale used, the main findings and the future recommendations of each work. After this, it was observed that 179 works could not be part of the final sample for not generating quantitative data or correlational variables between the antecedents and consequents of materialism. From this universe, 51 studies were not analyzed because they were qualitative; the remaining 128 studies were excluded for not presenting the object variables of this metaanalysis. Among the justified exclusions, 77 articles were selected, which generated 99 effect sizes between the construct materialism and the constructs antecedents and consequents.

A spreadsheet was also prepared, from which it was possible to encode the data to be analyzed. In this encoding, the titles of the studies, journal, author(s), year of publication, country of application of research, statistical indexes of studied relationships, reliability indexes, name and number of variables of applied scales were included. Specifically for data analysis, the correlation coefficient $r$ was used as a metric variable to measure the effects on the variables of the study scope. For studies reporting no $r$ correlation, the statistics that presented, for example, $\chi^{2}, f$-test, $t$-test, $z$-test and $\beta$-values were converted into correlation coefficients. This procedure is recommended by Hedges and Olkin (1985).
We emphasize that data encoding was conducted by four marketing researchers. Each article was examined by a single examiner. Before the beginning of this activity, analysis criteria were widely discussed among the authors of this study. In addition, for articles that raise questions about data extraction, meetings were held with two experts and an author, who acted as a judge. To complement this, 20 studies were randomly selected for the review of data encoding, resulting in an index of $95 \%$ of concordance between the studies reviewed by the researchers and those reviewed by the judge.

After the preparation of the database, it was investigated from the perspective of the variables proposed in the theoretical model, i.e., materialism and its antecedents (hedonic value perception, interpersonal influence, life satisfaction and consumer income, gender and age) and consequents (buying intention, impulsive buying, compulsive shopping, conspicuous consumption, status consumption and consumer involvement) were analyzed. In addition, and as shown in the data analysis section, this study also assessed the possible effects of methodological moderators on significant (consequent and antecedent) relationships which analyzed at least ten studies (Hunter \& Schmidt, 2004).

\section{Analysis results}

Altogether, 77 articles were analyzed to conduct this study. This analysis included studies that were carried out between 1982 and 2014. Many studies have been published over the present decade, i.e., between 2010 and 2014: a total 62 . These data further justify this study. Of the total universe, there were surveys with a minimum of 82 and a maximum of 2,206 respondents, accumulating a total sample of 40,288. The materialism construct Cronbach's Alpha varied between 0.57 and $0.91(M=0.78)$. There was not a correlation between year of publication and sample size.

Table 1 shows a summary of the results obtained in the meta-analysis. We emphasize that 
the effects found in the analyzed articles were encoded and transformed into Pearson productmoment correlation $r$. Next, correlations were adjusted for the sample size and reliability indexes of the scales used. These procedures aim to reduce sampling error and correct measurement error (Hunter \& Schmidt, 2004).

\section{I Materialism antecedents}

Based on the indexes shown in Table 1, the hypothesis $H_{1}$ is confirmed, suggesting a positive and significant correlation between hedonic value perception and materialism. The assumption was based on the relationship between hedonic value perception and sense of ownership, based on symbols and experiences, detected in materialistic features (Micken \& Roberts, 1999). The findings consolidate this assumption, since the relationship was significant and positive with a $\rho=0.378$ $(p<0.001)$. In this case, 12 works were required to reject the results (fail safe number).

Next, evaluating the results of hypothesis $H_{2}$ a significant positive relationship was observed between interpersonal influence and materialism $(\rho=0.302 ; p<0.001)$. This means that individuals more susceptible to influences of others tend to present more materialistic characteristics. It also enables the assumption that the materialistic individual shows a greater need for acceptance and inclusion in a community (Micken \& Roberts, 1999; Chang \& Arkin, 2002; Gil et al., 2016).
The fail safe number detected in the analysis was 13 studies.

For hypothesis $H_{3}, 8$ studies were analyzed, which generated 9 effect sizes, by which it was possible to observe a significant negative relationship between life satisfaction and materialistic consumption $(\rho=-0.203, p<0.001$; fail safe number $=9$ ).

From the presented results, it is possible to support hypothesis $\mathrm{H}_{3}$ and also strengthen the proposition that individuals with depression (Kasser \& Ryan, 1993), isolation (Richins \& Dawson, 1992) and life dissatisfaction characteristics tend to be more materialistic (Kasser, 2002; Rakrachakarn et al., 2015; Gungordu et al., 2016).

Finally, the last hypotheses related to materialism antecedents are associated with sociodemographic income $\left(H_{4}\right)$, gender $\left(H_{5}\right)$ and age $\left(H_{\sigma}\right)$. It was assumed, at first, a positive relationship between consumer income and materialism, a fact supported by the results $(\rho=0.108, p<0.01$; fail safe number $=6)$. It was also expected a positive relationship with the female gender. In this case, the relationship was not statistically supported $(\rho=0.021$; $p=0.063)$. Finally, an inverse relationship (negative) was expected between age and materialism. The results again were not sufficient to support the proposition $(\rho=-0.048$, $p=0.128)$. 
Table 1

Summary of meta-analytic results

\begin{tabular}{|c|c|c|c|c|c|c|c|c|c|c|c|c|c|c|}
\hline Relationship & $(\mathbf{k})$ & (o) & $\mathbf{N}$ & Min & $\operatorname{Max}$ & $\mathbf{r}_{s}$ & $\mathbf{R}$ & $\rho$ & $\operatorname{sig}_{1}$ & $\begin{array}{c}\text { LCI } \\
(95 \%)\end{array}$ & $\begin{array}{c}\text { UCI } \\
(95 \%)\end{array}$ & $\mathbf{Q}$ & sig $_{2}$ & $\begin{array}{l}\text { fail safe } \\
\text { number }\end{array}$ \\
\hline \multicolumn{15}{|l|}{ Antecedents: } \\
\hline $\begin{array}{l}\text { Hedonic value } \\
\text { perception }\end{array}$ & 5 & 12 & 4,474 & 0.193 & 0.440 & 0.319 & 0.295 & 0.378 & 0.000 & 0.32 & 0.44 & 38.92 & 0.000 & 12 \\
\hline $\begin{array}{l}\text { Interpersonal } \\
\text { influence }\end{array}$ & 9 & 13 & 3,072 & -0.120 & 0.542 & 0.223 & 0.242 & 0.302 & 0.000 & 0.15 & 0.46 & 170.09 & 0.000 & 13 \\
\hline $\begin{array}{l}\text { Life } \\
\text { satisfaction }\end{array}$ & 8 & 9 & 8,528 & -0.410 & 0.170 & -0.173 & -0.155 & -0.203 & 0.000 & -0.29 & -0.11 & 80.90 & 0.000 & 9 \\
\hline Income & 6 & 6 & 2,690 & 0.030 & 0.229 & 0.123 & 0.108 & 0.108 & 0.002 & 0.04 & 0.17 & 16.18 & 0.006 & 6 \\
\hline Gender & 14 & 15 & 6,041 & -0.179 & 0.160 & -0.045 & 0.021 & 0.021 & 0.063 & -0.09 & 0.04 & 85.62 & 0.000 & $\mathrm{NC}$ \\
\hline Age & 17 & 18 & 8,794 & -0.260 & 0.140 & -0.074 & -0.039 & -0.048 & 0.128 & -0.11 & 0.02 & 132.89 & 0.000 & $\mathrm{NC}$ \\
\hline \multicolumn{15}{|l|}{ Consequents: } \\
\hline $\begin{array}{l}\text { Buying } \\
\text { intention }\end{array}$ & 12 & 15 & 4,874 & -0.159 & 0.430 & 0.226 & 0.195 & 0.245 & 0.000 & 0.12 & 0.36 & 170.16 & 0.000 & 15 \\
\hline $\begin{array}{l}\text { Impulsive } \\
\text { buying }\end{array}$ & 8 & 8 & 3,506 & 0.123 & 0.565 & 0.296 & 0.278 & 0.351 & 0.000 & 0.25 & 0.45 & 51.82 & 0.000 & 8 \\
\hline $\begin{array}{l}\text { Compulsive } \\
\text { shopping }\end{array}$ & 17 & 19 & 5,935 & -0.440 & 0.900 & 0.337 & 0.382 & 0.452 & 0.000 & 0.33 & 0.60 & 390.19 & 0.000 & 19 \\
\hline $\begin{array}{l}\text { Conspicuous } \\
\text { consumption }\end{array}$ & 5 & 8 & 2,671 & 0.130 & 0.670 & 0.419 & 0.386 & 0.479 & 0.000 & 0.30 & 0.68 & 179.59 & 0.000 & 8 \\
\hline $\begin{array}{l}\text { Status } \\
\text { consumption }\end{array}$ & 13 & 20 & 9,551 & 0.020 & 0.664 & 0.436 & 0.438 & 0.560 & 0.000 & 0.46 & 0.66 & 408.25 & 0.000 & 20 \\
\hline $\begin{array}{l}\text { Consumer } \\
\text { involvement }\end{array}$ & 7 & 7 & 2,575 & 0.129 & 0.508 & 0.346 & 0.316 & 0.390 & 0.000 & 0.22 & 0.54 & 65.26 & 0.000 & 7 \\
\hline
\end{tabular}

Notes: $\mathrm{k}$ = number of studies used for analysis; $\mathrm{o}=$ number of observations extracted from studies for analysis; $\mathrm{N}$ = number of samples accumulated in evaluated studies; Min = minimum effect size found in studies; Max $=$ maximum effect size found in studies; $r$ simple average of effect sizes found in studies; $r=$ weighted and corrected average of effect sizes extracted from studies; $\rho=$ average value of effect sizes corrected for measurement error variance in both variables, where $\rho=; \operatorname{sig}_{1}$ grau de significância do effect size $\left.;<\right\} 0\left\{>\right.$ sig ${ }_{1=}$ degree of significance of effect size; LCI = lower confidence interval; UCI = upper confidence interval; $Q=$ test for heterogeneity at individual and aggregate levels; $\operatorname{sig}_{2}=$ degree of significance of $Q$; fail safe number $=$ number of studies needed for result to be false; $\mathrm{NC}=$ not calculated, since the effect size was not significant $(p>0.05)$.

\subsection{Consequents of materialism}

The analysis of the consequents of materialism begins with hypothesis $H_{7}$ A positive relationship with buying intention was expected. Results obtained from the evaluation of nine studies, generating 15 effect sizes, confirmed this assumption, showing an effect $\rho=0.245$ $(p<0.001)$, requiring 15 studies to reject the findings (fail safe number). This result is in line with the conclusions reached over nearly two decades of studies (Browne \& Kaldenberg, 1997; Park et al., 2008; Loureiro \& Araújo, 2014; Sun et al., 2016).
For hypotheses $H_{8}$ and $H_{9}$, it was expected, respectively, a positive relationship of materialism with impulsive buying and compulsive shopping. The assumptions are based on the interpretation that both impulsive buying and compulsive shopping are strongly derived from environmental stimuli, a feature detected in consumers with materialistic characteristics (Fitzmaurice \& Comegys, 2006). The results indicated this line of interpretation, given that the strength of the relationship between materialism and impulsive buying was $\rho=0.351(p<0.001)$ and the relationship between materialism and compulsive 
shopping was $\rho=0.452(p<0.001)$. The number of studies required to reject the results of the hypothesis $H_{8}$ is 8 and the hypothesis $H_{9}$ is 19 . The results corroborated and provided a greater solidity to studies that had already detected these relationships (Arocas et al., 2004; Moschis et al., 2013; Lee et al., 2014; Cakarnis \& D'Alessandro, 2015).

Next, hypotheses whose propositions led to expect a positive relationship between materialism and conspicuous consumption $\left(H_{10}\right)$ and between materialism and status consumption $\left(H_{11}\right)$ were tested. According to the referred indexes, both hypotheses were confirmed $\left(H_{10}: \rho=0.479, p<0.001\right.$, fail safe number $=$ 8; $H_{11}: \rho=0.560, p<0.001$, fail safe number $=$ 20 ). According to the findings, it is concluded that materialistic behavior raises the possibility of the consumer purchasing expensive and not needed goods in order to draw the attention of others (Shukla, 2008), as well as to stimulate an individual status identification (O'Cass \& McEwen, 2004; Chan et al., 2015). Moreover, the results are in line with previous research findings (Kasser, 2002; Shukla, 2012; Loureiro \& Araújo, 2014)

Finally, the last consequent analyzed $\left(H_{12}\right)$ relates to a possible materialist relationship with consumer involvement. It was suspected that the greater the materialism, the greater the consumer involvement for goods, since one of the characteristics of a materialistic individual is attention expended to purchase and ownership of goods (Belk, 1985; Manchiaraju, 2015). The results support $\mathrm{H}_{12}$, because the strength of the relationship was significant and positive ( $\rho=0.390, p<0.001)$. Moreover, it is noted that seven studies with opposite results are required (fail safe number) for the rejection of the findings.

To finish the analysis of antecedents and consequents of the studied construct, Figure 2 presents an overview of data obtained through a forest plot.

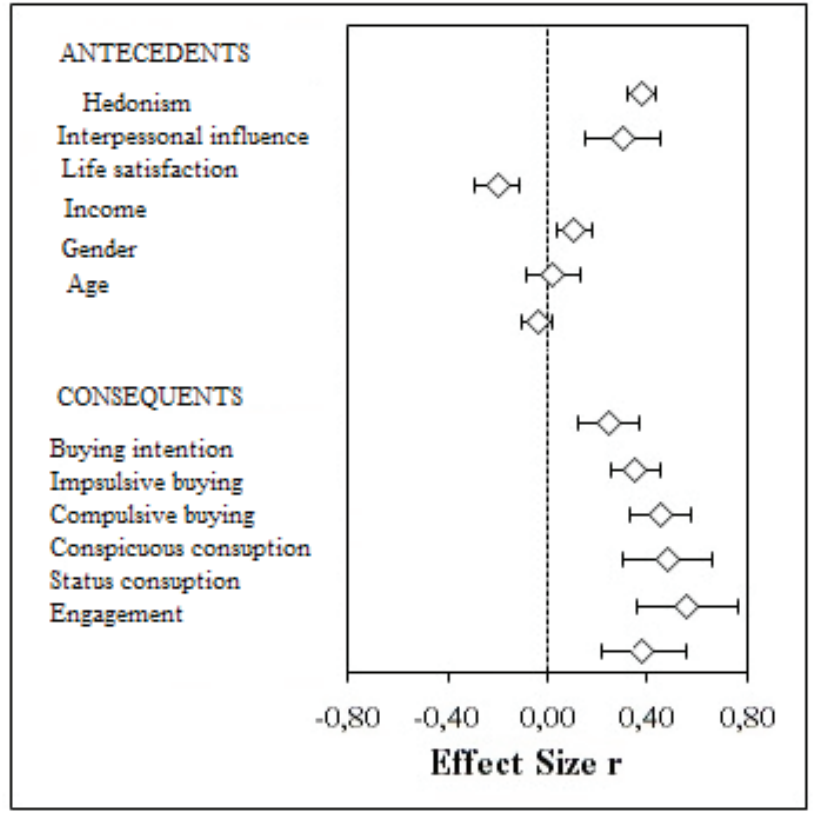

Figure 2. Forest plot of antecedents and consequents

As we can see, the antecedent constructs of materialism present greater variability in relationship to their effects, whether negative (life satisfaction), null (gender and age) or positive (hedonic value perception, interpersonal influence and income). On the other hand, when observing the relationship of effects for consequent constructs, all have a significant positive relationship with materialism, showing less variation in behavior.

\subsection{Analysis of moderator effects on relationships found by hypotheses}

As mentioned in the methods section, some analyses were performed regarding possible effects of methodological moderators that could interfere with the relationships between antecedents and consequents of materialism. In total, four equations were examined: sample type (students vs. non-students), research location (field vs. laboratory), sample size (small vs. large) and country of application of the study (West vs. East).

It should be noted that the analysis was only applied in the following situations: $i$ ) when 
the number of analyzed studies was equal to or greater than 10 since less than 10 studies would be insufficient to notice changes in behavior caused by moderators (Hunter \& Schmidt, 2004); and ii) when direct relationships were significant. Thus, a test was conducted to verify the moderating effects of methodological applications involving materialism and the consequents associated with buying intention, compulsive shopping and status consumption. The tests of relationships are shown in Table 2.
After the investigations started, at first a possible moderating effect on sample type (students vs. non-students) was not identified, since the difference among groups was not significant (buying intention, compulsive shopping and status consumption). In view of the results presented, it is concluded that sample type does not affect the relationships between materialism and its consequents. Also note the rejection of a possible moderating effect of study location (laboratory vs. field).

Table 2

\section{Moderation test}

\begin{tabular}{|c|c|c|c|c|c|c|c|c|c|}
\hline \multirow{2}{*}{ Moderating variables } & \multicolumn{3}{|c|}{ Compulsive shopping } & \multicolumn{3}{|c|}{ Status consumption } & \multicolumn{3}{|c|}{ Buying intention } \\
\hline & \multirow{2}{*}{$\begin{array}{l}\mathbf{N} \\
\rho\end{array}$} & \multicolumn{2}{|c|}{ Statistical tests } & \multirow{2}{*}{$\begin{array}{c}\mathbf{N} \\
\rho\end{array}$} & \multicolumn{2}{|c|}{ Statistical tests } & \multirow{2}{*}{$\begin{array}{c}\mathbf{N} \\
\rho\end{array}$} & \multicolumn{2}{|c|}{ Statistical tests } \\
\hline Sample Type & & & & & & & & & \\
\hline \multirow{4}{*}{ Non-students } & 13 & $F$ & 2,169 & 8 & $F$ & 0,214 & 8 & $F$ & 0,227 \\
\hline & 0,26 & $p$ & 0,159 & 0,41 & $p$ & 0,649 & 0,20 & $p$ & 0,642 \\
\hline & 6 & $\pi$ & 0,285 & 12 & $\pi$ & 0,072 & 7 & $\pi$ & 0,073 \\
\hline & 0,48 & $\eta^{2}$ & $11,3 \%$ & 0,45 & $\eta^{2}$ & $1,2 \%$ & 0,24 & $\eta^{2}$ & $1,7 \%$ \\
\hline \multicolumn{10}{|l|}{ Study location } \\
\hline \multirow{2}{*}{ Laboratory } & 7 & $F$ & 0,900 & 9 & $F$ & 1,226 & 7 & $F$ & 2,181 \\
\hline & 0,25 & $p$ & 0,356 & 0,48 & $p$ & 0,283 & 0,16 & $p$ & 0,164 \\
\hline \multirow{2}{*}{ Field } & 12 & $\pi$ & 0,146 & 11 & $\pi$ & 0,182 & 8 & $\pi$ & 0,278 \\
\hline & 0,38 & $\eta^{2}$ & $0,5 \%$ & 0,39 & $\eta^{2}$ & $64 \%$ & 0,28 & $\eta^{2}$ & $14,4 \%$ \\
\hline \multicolumn{10}{|l|}{ Sample size } \\
\hline \multirow{2}{*}{ Small } & 9 & $F$ & 2,085 & 11 & $F$ & 5,379 & 8 & $F$ & 5,915 \\
\hline & 0,23 & $p$ & 0,167 & 0,51 & $p$ & $<0,05$ & 0,30 & $p$ & $<0,05$ \\
\hline \multirow{2}{*}{ Large } & 10 & $\pi$ & 0,276 & 9 & $\pi$ & 0,593 & 7 & $\pi$ & 0,614 \\
\hline & 0,42 & $\eta^{2}$ & $10,9 \%$ & 0,39 & $\eta^{2}$ & $23 \%$ & 0,13 & $\eta^{2}$ & $31,3 \%$ \\
\hline \multicolumn{10}{|l|}{ Country } \\
\hline \multirow{2}{*}{ East } & 3 & $F$ & 2,797 & 3 & $F$ & 1,124 & 8 & $F$ & 7,950 \\
\hline & 0,59 & $p$ & 0,113 & 0,33 & $p$ & 0,303 & 0,19 & $p$ & $<0,05$ \\
\hline \multirow{2}{*}{ West } & 16 & $\pi$ & 0,352 & 17 & $\pi$ & 0,171 & 6 & $\pi$ & 0,735 \\
\hline & 0,28 & $\eta^{2}$ & $14,1 \%$ & 0,45 & $\eta^{2}$ & $5,9 \%$ & 0,33 & $\eta^{2}$ & $39,8 \%$ \\
\hline
\end{tabular}

Notes: $(N)$ : number of accumulated samples of evaluated studies; $(\rho)$ : average value of effect sizes corrected for measurement error variance for both variables; (F): F statistic, indicates the size of the difference among groups; (p): level of significance; $(\pi)$ : power test is the probability of not making a type II error; $\left(\eta^{2}\right)$ : eta-square, proportion of the variance in $\mathrm{Y}$ explained by $\mathrm{X}$.

The moderating effect of sample size (small vs. large) and the resulting consequent relationships of materialism were also analyzed.
Among all the equations, the aforementioned effects were present in only one equation (materialism and compulsive shopping). In other 
cases, there was the presence of a moderating effect of sample size on the tested relationships. The averages of effect sizes were always higher in studies with small samples (materialism and buying intention: $\rho_{\text {small }}=0.30 \mathrm{vs}$. $\rho_{\text {large }}=0.13$; materialism and status consumption: $\rho_{\text {small }}=0.51$ vs. $\left.\rho_{\text {large }}=0.39\right)$. In view of the findings, the assumption according to which small samples overestimate effect sizes indexes is strengthened (Hedges \& Olkin, 1985; Fern \& Monroe, 1996).

Finally, the possible moderating effect arising from the country where research was applied was also tested. In this case, and based on the assumption that Western cultures have a more individualistic orientation as opposed to Eastern cultures which present a collectivist nature (Hofstede, 1993), stronger effect sizes were expected for studies conducted in Western countries. According to the analysis, there was a confirmation of this supposition only for the relationship materialism and buying intention $\left(\rho_{\text {east }}=0.19\right.$ vs. $\left.\rho_{\text {west }}=0.33\right)$. For the other relationships, it was not possible to sustain the proposition. The presented results allow partially confirming possible moderating effects between the country of application of the study and the tested relationships.

Thus, Figure 3 shows the synthesis of the findings of this study based on the meta-analysis.

\section{ANTECEDENTS}

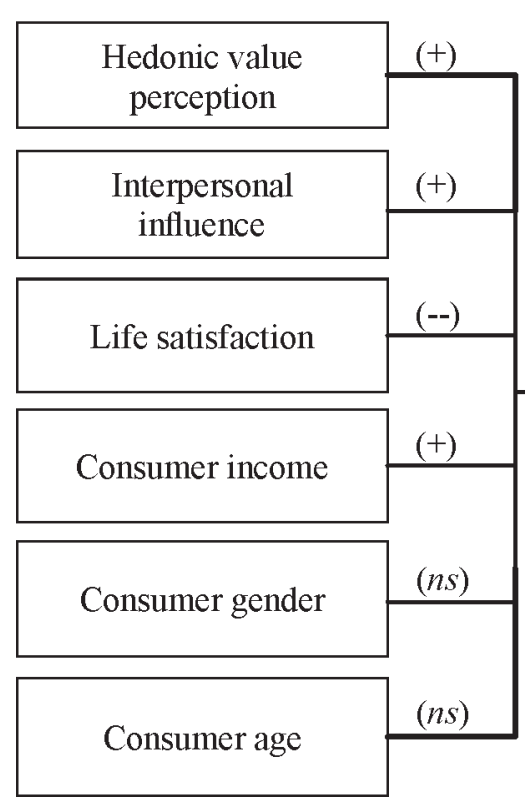

MODERATORS

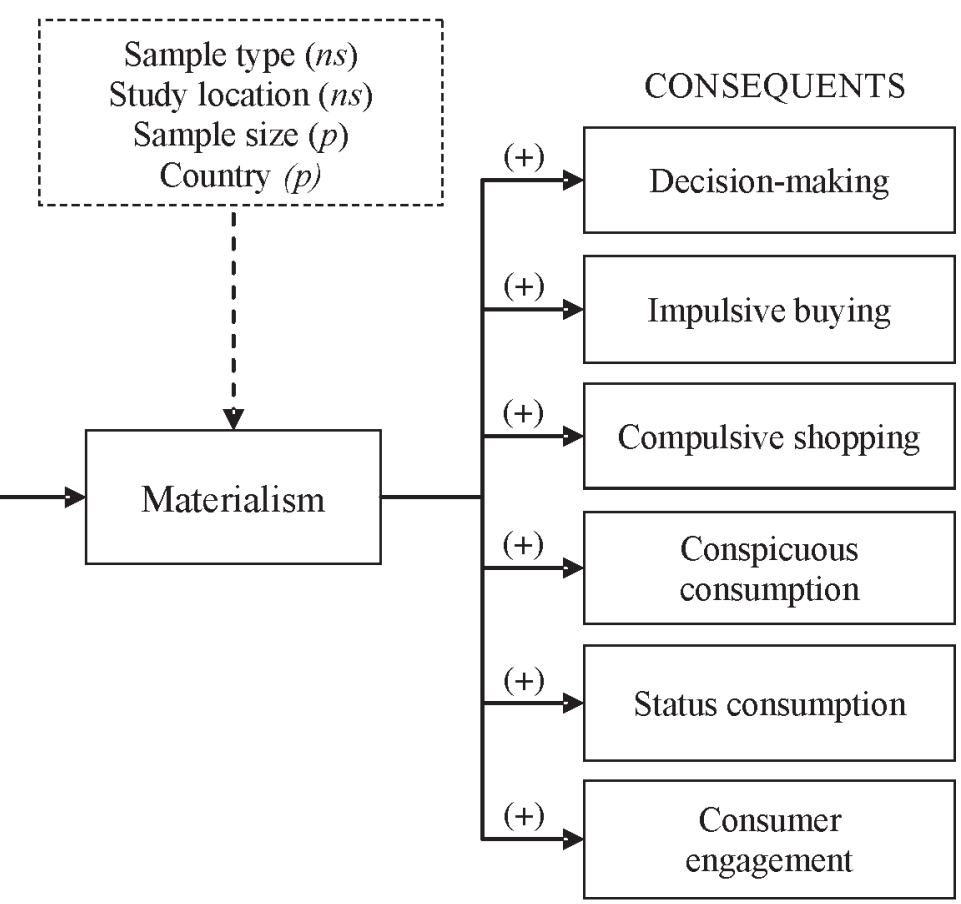

Figure 3. Research results

Note: (+) Positive and significant relationship; (-) negative and significant relationship; (ns) not significant relationship; $(p)$ partially confirmed relationship

\section{Final considerations}

This article suggested and tested a framework of antecedents and consequents of materialism. For this purpose, a meta-analysis was conducted, in which it was possible to quantitatively investigate the main findings associated with the analysis scope. The study contributes to academic studies in the following aspects.

First, statistical support was obtained to confirm the positive relationship of materialism 
antecedents with the constructs hedonic value perception, interpersonal influence and consumer income. Furthermore, inverse (negative) and significant relationships were detected for the antecedent life satisfaction. The results also strengthen theories stating that hedonism evokes a symbolic feeling of achievement, which characterizes materialism (Micken \& Roberts, 1999). Moreover, it was observed that interpersonal influence increases the materialistic behavior in search for social acceptance (Kropp et al., 2005), as well as that availability of financial resources increases the propensity of an individual to be materialistic (Santos \& Fernandes, 2011). The assumption that people dissatisfied with life show an increased need for material behavior was also evidenced (Kasser, 2002; Rakrachakarn et al., 2015).

Second, this study provided further consolidation for the construct materialism and its consequents because studies that evidenced a positive relationship between materialism and buying intention (Loureiro \& Araújo, 2014, Sun et al., 2016; among others), impulsive buying and compulsive shopping (Moschis et al., 2013; Lee et al., 2014, among others), conspicuous consumption and status consumption (Shukla, 2012; Sangkhawasi \& Johri, 2007, Segev et al., 2015; among others), and consumer involvement (Goldsmith et al., 2012; Handa \& Khare, 2013; Manchiraju, 2015; among others) were ratified.

Third, the facts that variables' sample size and country where research was applied potentiated the relationship between the investigated constructs and materialism was partially confirmed. In this case, the propositions according to which small samples tend to generate a greater strength of effect sizes (Hedges \& Olkin, 1985), and Western countries tend to have more materialistic characteristics than eastern countries (Hofstede, 1993) were reinforced.

In addition to the mentioned results, the contribution provided by this meta-analysis in providing a consistent theoretical review that resulted in a quantitative integration of key constructs related to antecedents and consequents of materialism is emphasized. Thus, this study shows different empirical evidence and contributes to a more comprehensive understanding of the effects investigated here.

Noteworthy is also that this study had some important limitations. This research was restricted to relationships of consumption and goods associated with materialism. Within this scope, only quantitative studies were analyzed. Thus, a wide range of qualitative work was not analyzed, which, due to the specificity of the techniques used, was not considered in the analysis. Thus, we suggest that further studies incorporate qualitative research based on methodologies different from meta-analysis.

It is also noted that one of the problems of this type of analysis is the exclusion of adverse concepts existing in the secondary data used. Therefore, it is emphasized that, since they are empirical data obtained from different authors, this data may be adverse. At this point, the construct consumer involvement is relevant since it is a comprehensive understanding and can be connected to a context or a consumer characteristic.

As for future research suggestions, we recommend that the possible antecedents and consequents which were not investigated in this meta-analysis - such as self-esteem, attitude, loyalty, among others - be investigated. The analysis of these constructs was not performed in this study due to the few empirical relationships found in the analyzed studies on materialism (less than three), revealing a gap for future research in marketing and psychology.

Finally, this article proposed to generate a theoretical and empirical model, and therefore generate an opportunity of insights by researchers and academics to better base their research on an approach to materialism and its antecedents and consequents.

\section{References}

Arocas, R., Puello Arrieta, S., \& Botero, M. M. (2004). La compra impulsiva y el materialismo en los jóvenes: Estudio exploratorio en estudiantes universitarios de Barranquilla (Colombia). Psicología Desde el Caribe, (14), 1-26. 
Bearden, W. O., Netemeyer, R. G., \& Teel, J. E. (1989). Measurement of consumer susceptibility to interpersonal influence. Journal of Consumer Research, 15(14), 473-481.

Beatty, S. E., \& Talpade, S. (1994). Adolescent influence in family decision making: A replication with extension. Journal of Consumer Research, 21(2), 332-341.

Belk, R. W. (1982). Acquiring, possessing, and collecting: Fundamental processes in consumer behavior. In R. F. Bush \& S. D. Hunt (Eds.), Marketing theory: Philosophy of science perspectives (pp. 185-190). Chicago American Marketing Association.

Belk, R. W. (1985). Materialism: Trait aspects of living in the material world. Journal of Consumer Research, 12(3), 265-280.

Benmoyal-Bouzaglo, S., \& Moschis, G. P. (2010). Effects of family structure and socialization on materialism: A life course study in France. The Journal of Marketing Theory and Practice, 18(1), 53-70.

Browne, B. A., \& Kaldenberg, D. O. (1997). Conceptualizing self-monitoring: Links to materialism and product involvement. Journal of Consumer Marketing, 14(1), 31-44.

Cakarnis, J., \& D'Alessandro, S. P. (2015). Does knowing overcome wanting? The impact of consumer knowledge and materialism upon credit card selection with young consumers. Young Consumers, 16(1), 50-70.

Chan, W. Y., To, C. K., \& Chu, W. C. (2015). Materialistic consumers who seek unique products: How does their need for status and their affective response facilitate the repurchase intention of luxury goods? Journal of Retailing and Consumer Services, 27, 1-10.

Chang, L., \& Arkin, R. M. (2002). Materialism as an attempt to cope with uncertainty. Psychology
\& Marketing, 19(5), 389-406.

Chang, J. H., \& Zhang, H. (2008). Analyzing online game players: From materialism and motivation to attitude. CyberPsychology \& Behavior, 11(6), 711-714.

Dickersin, K. (2002). Systematic reviews in epidemiology: Why are we so far behind? International Journal of Epidemiology, 31(1), 6-12.

Donnelly, G., Ksendzova, M., \& Howell, R. T. (2013). Sadness, identity, and plastic in overshopping: The interplay of materialism, poor credit management, and emotional buying motives in predicting compulsive buying. Journal of Economic Psychology, 39, 113-125.

Dubois, B. \& Duquesne, P. (1993). The market for luxury goods: Income versus culture. European Journal of Marketing, 27(1), 35-44.

Efrat, K., \& Shoham, A. (2013). The theory of planned behavior, materialism, and aggressive driving. Accident Analysis \& Prevention, 59, 459465.

Farley, J. U., Lehmann, D. R., \& Sawyer, A. (1995). Empirical marketing generalization using meta-analysis. Marketing Science, 14 (3 Supp.), G36-G46.

Fern, E. F., \& Moroe, K. B. (1996). Effect-Size estimates: Issues and problems in interpretation. Journal of Consumer Research, 23(2), 89-105.

Fitzmaurice, J., \& Comegys, C. (2006). Materialism and social consumption. The Journal of Marketing Theory and Practice, 14(4), 287-299.

Flynn, L. R., Goldsmith, R. E., \& Kim, W. M. (2013). A cross-cultural study of materialism and brand engagement. Journal of Multidisciplinary Research, 5(3), 49-70.

Gil, A. L., Leckie, C., \& Johnson, L. (2016). The impact of self on materialism among teenagers. Journal of Consumer Behaviour, 15(1), 281-288. 
Goldberg, M. E., Gorn, G. J., Peracchio, L. A., \& Bamossy, G. (2003). Understanding materialism among youth. Journal of Consumer Psychology, 13(3), 278-288.

Goldsmith, R. E., Flynn, L. R., \& Clark, R. A. (2012). Materialistic, brand engaged and status consuming consumers and clothing behaviors. Journal of Fashion Marketing and Management, 16(1), 102-119.

Green, S. (2005). Systematic reviews and metaanalysis. Singapore Medical Journal, 46(6), 270-273.

Grotts, A. S., \& Johnson, T. W. (2013). Millennial consumers' status consumption of handbags. Journal of Fashion Marketing and Management, 17(3), 280-293.

Gungordu, A., Yilmaz, K. G., \& Yumusak, T. (2016). Examining the causal relationships between materialism, status consumption and life satisfaction. Journal of Research in Business, Economics and Management, 5(5), 781-789.

Handa, M., \& Khare, A. (2013). Gender as a moderator of the relationship between materialism and fashion clothing involvement among Indian youth. International Journal of Consumer Studies, 37(1), 112-120.

Hedges, L. V., \& Olkin, I. (1985). Statistical methods for meta-analysis. Orlando, FL: Academic Press.

Hofstede, G. (1993). Cultural constraints in management theories. The Academy of Management Executive, 7(1), 5-21.

Holbrook, M. B., \& Hirschman, E. C. (1982). The experiential aspects of consumption: Consumer fantasies, feelings, and fun. Journal of Consumer Research, 9(2), 132-140.

Hudders, L., \& Pandelaere, M. (2012). The silver lining of materialism: The impact of luxury consumption on subjective well-being. Journal of Happiness Studies, 13(3), 411-437.
Hunter, J. E., \& Schmidt, F. L. (Eds.). (2004). Methods of meta-analysis: Correcting error and bias in research findings. Newbury Park, CA: Sage.

Joireman, J., Kees, J., \& Sprott, D. (2010). Concern with immediate consequences magnifies the impact of compulsive buying tendencies on college students' credit card debt. The Journal of Consumer Affairs, 43(1), 155-178.

Karabati, S., \& Cemalcilar, Z. (2010). Values, materialism, and well-being: A study with Turkish university students. Journal of Economic Psychology, 31(4), 624-633.

Kasser, T. (2002). The high price of materialism. Cambridge: MIT Press.

Kasser, T., \& Ryan, R. M. (1993). A dark side of the American dream: correlates of financial success as a central life aspiration. Journal of Personality and Social Psychology, 65(2), 410-422.

Kempf, D. S., Laczniak, R. N., \& Smith, R. E. (2006). The effects of gender on processing advertising and product trial information. Marketing Letters, 17(1), 5-16.

Kropp, F., Lavack, A. M., \& Silvera, D. H. (2005). Values and collective self-esteem as predictors of consumer susceptibility to interpersonal influence among university students. International Marketing Review, 22(1), 7-33.

Kruger, D., \& Byker, D. (2009). Evolved foraging psychology underlies sex differences in shoping experiences and behaviors. Journal of Social, Evolutionary, and Cultural Psychology, 3(4), 328342.

Lee, Y. K., Chang, C. T., Lin, Y., \& Cheng, Z. H. (2014). The dark side of smartphone usage: Psychological traits, compulsive behavior and technostress. Computers in Human Behavior, 31, 373-383.

Lewallen, J., Miller, B., \& Behm-Morawitz, E. (2016). Lifestyles of the rich and famous: Celebrity 
media diet and the cultivation of emerging adults' materialism. Mass Communication and Society, 19(3), 253-274.

Liao, S. L., Shen, Y. C., \& Chu, C. H. (2009). The effects of sales promotion strategy, product appeal and consumer traits on reminder impulse buying behaviour. International Journal of Consumer Studies, 33(3), 274-284.

Lipsey, M. W., \& Wilson, D. B. (2001). Practical meta-analysis (Vol. 49). Thousand Oaks, CA: Sage publications.

Loureiro, S. M. C., \& Araújo, C. M. B. D. (2014). Luxury values and experience as drivers for consumers to recommend and pay more. Journal of Retailing and Consumer Services, 21(3), 394-400.

Manchiraju, S, (2015). Extension of the tripartite model of body influence: The role of materialism on body satisfaction and fashion involvement (Tese de doutorado). Iowa State University, Iwoa, United States.

McCullough, M. E., Emmons, R. A., \& Tsang, J. A. (2002). The grateful disposition: A conceptual and empirical topography. Journal of Personality and Social Psychology, 82(1), 112.

Micken, K. S., \& Roberts, S. D. (1999). Desperately seeking certainty: Narrowing the materialism construct. Advances in Consumer Research, 26(1), 513-518.

Miller, N. G. (2000). Retail leasing in a web enabled world. Journal of Real Estate Portfolio Management, 6(2), 167-184.

Moher, D., Liberati, A., Tetzlaff, J., \& Altman, D. G. (2009). Preferred reporting items for systematic reviews and meta-analyses: The PRISMA statement. Annals of Internal Medicine, 151(4), 264-269.

Moschis, G. P., Mathur, A., Fatt, C. K., \& Pizzutti, C. (2013). Effects of family structure on materialism and compulsive consumption: A life course study in Brazil. Journal of Research for Consumers, (23), 66-96.

O'Cass, A., \& McEwen, H. (2004). Exploring consumer status and conspicuous consumption. Journal of Consumer Behaviour, 4(1), 25-39.

O'Guinn, T. C., \& Faber, R. J. (1989). Compulsive buying: A phenomenological exploration. Journal of Consumer Research, 16(2), 147-157.

Park, J., \& Lennon, S. J. (2006). Psychological and environmental antecedents of impulse buying tendency in the multichannel shopping context. Journal of Consumer Marketing, 23(2), 56-66.

Park, H.-J., Rabolt, N. J., \& Jeon, K. S. (2008). Purchasing global luxury brands among young Korean consumers. Journal of Fashion Marketing and Management, 12(2), 244-259.

Rakrachakarn, V., Moschis, G. P., Ong, F. S., \& Shannon, R. (2015). Materialism and life satisfaction: The role of religion. Journal of Religion and Health, 54(2), 413-426.

Reeves, R. A., Baker, G. A., \& Truluck, C. S. (2012). Celebrity worship, materialism, compulsive buying, and the empty self. Psychology \& Marketing, 29(9), 674-679.

Richins, M. L. (2004). The material values scale: Measurement properties and development of a short form. Journal of Consumer Research, 31(1), 209-219.

Richins, M. L., \& Dawson, S. (1992). A consumer values orientation for materialism and its measurement: Scale development and validation. Journal of Consumer Research, 19(3), 303-316.

Richins, M. L., \& Chaplin, L. N. (2015). Material parenting: how the use of goods in parenting fosters materialism in the next generation. Journal of Consumer Research, 41(6), 1333-1357. 
Roberts, J. A., \& Clement, A. (2007). Materialism and satisfaction with over-all quality of life and eight life domains. Social Indicators Research, 82(1), 79-92.

Santos, C. P., \& Fernandes, D. V. (2011). A socialização de consumo e a formação do materialismo entre adolescentes. Revista de Administração Mackenzie, 12(1), 169-203.

Shin, D. C., \& Johnson, D. M. (1978). Avowed happiness as an overall assessment of the quality of life. Social Indicators Research, 5(4), 475-492.

Sangkhawasi, T., \& Johri, L. M. (2007). Impact of status brand strategy on materialism in Thailand. Journal of Consumer Marketing, 24(5), 275-282.

Schmidt, F. L. (1996). Statistical significance testing and cumulative knowledge in psychology: Implications for training of researchers. Psychological Methods, 1(2), 115-129.

Segev, S., Shoham, A., \& Gavish, Y. (2015). A closer look into the materialism construct: The antecedents and consequences of materialism and its three facets. Journal of Consumer Marketing, 32(2), 85-98.

Shukla, P. (2008). Conspicuous consumption among middle age consumers: Psychological and brand antecedents. Journal of Product \& Brand Management, 17(1), 25-36.

Shukla, P. (2012). The influence of value perceptions on luxury purchase intentions in developed and emerging markets. International Marketing Review, 29(6), 574-596.

Sun, G., Wang, W., Cheng, Z., Li, J., \& Chen, J. (2017). The intermediate linkage between materialism and luxury consumption: Evidence from the emerging market of China. Social Indicators Research, 132(1), 475-487.

Sun, T., \& Wu, G. (2011). Trait predictors of online impulsive buying tendency: A hierarchical approach. Journal of Marketing Theory and Practice, 19(3), 337-346.

Truong, Y., Simmons, G., McColl, R., \& Kitchen, P. J. (2008). Status and conspicuousness-are they related? Strategic marketing implications for luxury brands. Journal of Strategic Marketing, 16(3), 189-203.

Tsang, J. A., Carpenter, T. P., Roberts, J. A., Frisch, M. B., \& Carlisle, R. D. (2014). Why are materialists less happy? The role of gratitude and need satisfaction in the relationship between materialism and life satisfaction. Personality and Individual Differences, 64, 62-66.

Yang, C., De Wang, Y., \&Niu, H. J. (2008). The effects of idolatry and personality traits on impulse buying: An empirical study. International Journal of Management, 25(4), 633-640.

Wan, W. W., Luk, C. L., Yau, O. H., Alan, C. B., Sin, L. Y., Kwong, K. K., \& Chow, R. P. (2009). Do traditional Chinese cultural values nourish a market for pirated CDs? Journal of Business Ethics, 88(1), 185-196.

Ward, S., \& Wackman, D. B. (1972). Children's Purchase Influence Attempts and Parental Yielding. Journal of Marketing Research (JMR), 9(3), 316-319.

Watson, J. J. (2003). The relationship of materialism to spending tendencies, saving, and debt. Journal of economic psychology, 24(6), 723739.

Weaver, S. T., Moschis, G. P., \& Davis, T. (2011). Antecedents of materialism and compulsive buying: A life course study in Australia. Australasian Marketing Journal, 19(4), 247-256.

Zaman, S., Shah, S. A. M., \& Hasnu, S. A. F. (2016). Targeting young consumers: How family, friends and advertisement shape materialism in Pakistan. Mediterranean Journal of Social Sciences, 7(4), 703-715. 


\section{About the authors:}

1. Fernando de Oliveira Santini, Doctor in Business, Pontifícia Universidade Católica do Rio Grande do Sul (PUC-RS), Brazil. E-mail: santiniconsultores@gmail.com

ORCID

(iD) 0000-0002-2161-0313

2. Wagner Júnior Ladeira, Doctor in Business, Universidade Federal do Rio Grande do Sul (UFRGS), Brazil.E-mail: wjladeira@gmail.com

ORCID

(iD) 0000-0002-1793-6206

3. Cláudio Hoffmann Sampaio, Doctor in Business, Universidade Federal do Rio Grande do Sul (UFRGS), Brazil. E-mail: csampaio@pucrs.br

ORCID

(iD) 0000-0001-9943-1414

4. Clécio Falcão Araújo, Master in Business, Pontifícia Universidade Católica do Rio Grande do Sul (PUCRS), Brazil. E-mail: clecioa@bol.com.br

ORCID

(iD) 0000-0002-8753-5184

\section{Contribution of each author:}

\begin{tabular}{|c|c|c|c|c|}
\hline Contribution & $\begin{array}{c}\text { Fernando de Oliveira } \\
\text { Santini }\end{array}$ & $\begin{array}{l}\text { Wagner Júnior } \\
\text { Ladeira }\end{array}$ & $\begin{array}{c}\text { Cláudio Hoffmann } \\
\text { Sampaio } \\
\end{array}$ & $\begin{array}{c}\text { Clécio Falcão } \\
\text { Araújo }\end{array}$ \\
\hline 1. Definition of research problem & $\sqrt{ }$ & $\sqrt{ }$ & $\sqrt{ }$ & $\sqrt{ }$ \\
\hline $\begin{array}{l}\text { 2. Development of hypotheses or research } \\
\text { questions (empirical studies) }\end{array}$ & $\sqrt{ }$ & $\sqrt{ }$ & $\sqrt{ }$ & \\
\hline $\begin{array}{l}\text { 3. Development of theoretical propositions } \\
\text { (theoretical work) }\end{array}$ & $\sqrt{ }$ & $\sqrt{ }$ & $\sqrt{ }$ & \\
\hline 4. Theoretical foundation / Literature review & $\sqrt{ }$ & $\sqrt{ }$ & & \\
\hline 5. Definition of methodological procedures & $\sqrt{ }$ & $\sqrt{ }$ & & \\
\hline 6. Data collection & $\sqrt{ }$ & & & $\sqrt{ }$ \\
\hline 7. Statistical analysis & $\sqrt{ }$ & & & \\
\hline 8. Analysis and interpretation of data & $\sqrt{ }$ & $\sqrt{ }$ & $\sqrt{ }$ & $\sqrt{ }$ \\
\hline 9. Critical revision of the manuscript & $\sqrt{ }$ & $\sqrt{ }$ & $\sqrt{ }$ & \\
\hline 10. Manuscript writing & $\sqrt{ }$ & $\sqrt{ }$ & $\sqrt{ }$ & \\
\hline
\end{tabular}

